\title{
Initial Public Offerings in Hot and Cold Markets
}

\author{
Jean Helwege and Nellie Liang \\ Federal Reserve Bank of New York \\ and \\ Board of Governors of the Federal Reserve System
}

First draft: March 1995

This draft: August 1996

The analysis and conclusions of this paper are those of the authors and do not indicate concurrence by other members of the research staff, by the Board of Governors, by the Federal Reserve Bank of New York, or by the Federal Reserve System.

We are grateful for helpful suggestions from Michael Fleming, David Ikenberry, Frank Packer, Katherine Spiess, and seminar participants at the Federal Reserve Bank of New York. Kyle Nagel, Philibert De Imus, Kevin Cole and Kin Cheng provided excellent research assistance. 


\title{
Initial Public Offerings in Hot and Cold Markets
}

\begin{abstract}
Asymmetric information models characterize hot IPO markets as periods when better quality firms have an incentive to issue equity, and cold markets as periods when the lemons premium associated with equity is too high to draw in many issuers. Recent empirical evidence, however, suggests that firms that issue in hot markets are a major source of stock price underperformance of equity issuers. We investigate these opposing views with data on IPO firms that issued in 1983, a hot market, and 1988, a cold market. We find that the two sets of firms have similar operating performance, but stock returns are worse for firms that went public in the hot market. Our results are largely consistent with investor overoptimism in hot markets, but not with the asymmetric information models.
\end{abstract}

Nellie Liang

Board of Governors of the Federal Reserve System

Division of Research and Statistics

Capital Markets Section

Mail Stop 89

Washington, DC 20551

(202) 452-2918

(202) 452-3819 FAX

Jean Helwege

Capital Markets Department

3rd Floor

Federal Reserve Bank of New York

33 Liberty St.

New York, NY 10045

(212) $720-5493$

(212) 720-1773 FAX 


\section{Initial Public Offerings in Hot and Cold Markets}

The initial public offering (IPO) market follows a cycle with dramatic swings, often referred to as hot and cold markets (e.g., Ibbotson and Jaffe (1975) and Ritter (1984)). A hot IPO market is characterized by an unusually high volume of offerings, severe underpricing, frequent oversubscription of offerings, a preponderance of smaller issues, and, to a certain extent, by concentrations in particular industries. ${ }^{1}$ In contrast, cold PO markets have much lower issuance, less underpricing, fewer instances of oversubscription, and larger offerings. Some researchers have argued that these swings in the IPO market reflect changes in investor sentiment, while others have argued they arise from changes in factors that affect the decision to issue equity, such as asymmetric information between investors and firms.

The decision to issue equity in an asymmetric information setting has been examined in signaling models of IPO underpricing (e.g., Allen and Faulhaber (1989)), the decision to go public (Chemmanur and Fulghieri (1995)), and the timing of the decision to complete a seasoned equity offering (SEO) (e.g., Choe, Masulis and Nanda (1993), Bayless and Chaplinsky (1996), and Lucas and McDonald (1990)). ${ }^{2}$ In nearly all of these models, the hot issue markets occur when better quality firms are pulled into the equity market as pricing becomes more favorable. In the IPO signaling models, hot markets typically occur when certain industries experience positive shocks to expected profitability that lead to a lower lemons premium. In the SEO models, the costs of asymmetric information are lower in some periods due to better investment opportunities, less asymmetric information, or random positive price changes.

The empirical evidence describing issuers in hot and cold markets is mixed. Choe et al. and Bayless and Chaplinsky provide evidence that announcement effects are less negative in hot markets, suggesting that better quality firms issue equity in hot markets. Tests of the IPO

${ }^{1}$ For example, Ritter (1984) shows that most of the underpricing in the hot issue market of $1980-1981$ is attributable to underpricing among IPOs in the natural resources sector.

${ }^{2}$ There are many modeis of the decision to issue equity or to change the debt/equity ratio. We focus here on models with direct implications for issuance in hot and cold markets. 
signaling models by Jegadeesh, Weinstein, and Welch (1993), Michaely and Shaw (1994) and Spiess and Pettway (1995) cast doubt on the strength of the relationship between underpricing and firm quality, suggesting that hot issue markets may not reflect greater participation by high quality IPOs. More recent evidence on the poor long-term stock price performance of equity issuers (e.g., Spiess and Affleck-Graves (1995), and Loughran and Ritter (1995)) suggests that equity issuers are below-average quality firms, especially if they issue equity in a hot market. Loughran and Ritter, in particular, argue that the underperformance results are evidence of investor overoptimism and managers' willingness to take advantage of such sentiments.

In this paper, we analyze IPOs that were completed in two very different markets, the hot IPO market of 1983 and the relatively cold IPO market of 1988 , to evaluate whether hot market issuers are higher quality firms as predicted by the asymmetric information models. While managers' views of their firms relative to the market's are difficult to measure, this problem is mitigated by our choice of distinct market conditions since managers reveal their beliefs about relative valuation through the timing of their IPOs. That is, asymmetric information models imply that hot market issuers are firms that consider themselves to have better prospects than the firms that accepted cold market pricing. We examine the 1983 and 1988 IPO firms assuming they are drawn from the same value distribution. Because they are separated by five years, we also examine a (small) set of IPO firms in 1982. These issuers most certainly are drawn from the same distribution as the 1983 firms, differing mainly in that the 1982 issuers did not delay their offerings.

We consider IPO firms' operating performance and stock returns for up to five years after the IPO, assuming that firm quality would be revealed during this period. We find that in the year of the IPO the hot market firms of 1983 are less profitable and somewhat smaller than the firms that went public in 1988; nor do they appear to have greater growth potential. In the years following the $\mathbb{P O}$, both sets of firms exhibit some deterioration in profits, from abnormaily high levels in the year of the IPO, but neither set underperforms other firms in the same industry. Indeed, operating performances of the two sets of firms are indistinguishable. Nevertheless, stock returns for the hot market IPO firms are quite poor for several years, whereas returns for the cold market IPO stocks are more comparable to those on NASDAQ stocks. We find no evidence that 
the hot market IPO firms are superior firms, as the asymmetric information models predict. Nor do we find, however, that the hot market firms are inferior, as the underperformance literature suggests. We do find evidence consistent with the view that excessively positive investor sentiment during hot markets leads to long-term underperformance. In particular, the same type of firm has lower stock returns if it comes public in a hot market.

The paper is organized as follows: Section II is a review of the theory and evidence on IPO cycles. We describe our data in Section III and provide evidence that our samples are appropriate for studying hot and cold IPOs. Section IV examines the operating performance and stock returns of the two sets of firms. Because the timing of the IPOs in our sample are separated by five years, it is possible that the good IPO firms in 1983 are drawn from a different distribution than the good IPO firms of 1988. Thus, in Section V we compare the 1983 hot market IPOs to another set of cold market İPOs that are more likely to be drawn from the same distribution - firms that came public in the cold market of 1982. Section VI is a discussion of the relationship between stock market returns and operating performance in light of varying investor sentiment over the IPO cycle. Section VII is the conclusion.

\section{IPO Cycles: Theory and Evidence}

In this section we discuss asymmetric information theories that explain why the volume of equity issuance varies over time. These theories include models of both IPOs and SEOs because the empirical literature on underperformance shows that both types of equity offerings result in poor long-run returns. We continue with a summary of the empirical evidence vis-a-vis the theories' predictions about hot and cold equity markets, as well as empirical results that suggest market inefficiency.

\section{A. Models of Equity Issuance in Hot and Cold Markets}

The IPO signaling models of underpricing, such as those of Allen and Faulhaber (1989), Welch (1989) and Grinblatt and Hwang (1989), show that underpricing equilibria can occur when better firms find underpricing a viable way to signal higher quality. These firms have an incentive to signal their quality so that their subsequent equity offerings will receive more favorable pricing. Allen and Faulhaber specifically address hot issue markets. Hot markets and 
underpricing equilibria (which are infrequent) occur when there are positive shocks to the expected profitability of firms. Since firms can signal their quality, more high quality firms will find it optimal to undertake IPOs. Accordingly, hot issue markets are associated with unusually high expected profits and they should last only as long as it takes competition to drive down profits in the industry.

An alternate view of IPO behavior is offered by Chemmanur and Fulghieri (1995), who focus on the volume of offerings in hot markets rather than on underpricing. They model the decision to go public or raise private equity from venture capitalists based on the degree to which asymmetric information affects pricing and the cost of reducing information problems. Hot markets occur when productivity shocks that increase the value of the firm induce more investors to produce information. This in turn leads to a greater incentive to go public. Thus, they characterize hot markets as a large number of offerings by unusually profitable firms. ${ }^{3}$

Choe, Masulis and Nanda (1993) present a model in which the degree of asymmetric information associated with SEOs varies with the business cycle. When the economy is growing, all firms receive projects with higher expected cash flows. This implies that in an expansion more firms will find it optimal to issue equity even in the face of the lemons premium. In essence, asymmetric information becomes less of a problem in an expanding economy, giving better quality firms a larger incentive to issue equity. ${ }^{4} \mathrm{~A}$ direct prediction of their model is that announcement effects for SEOs should be less negative during business cycle upswings because those periods lead to higher investors' expectations of the quality of the average issuer.

Bayless and Chaplinsky (1996) argue that hot issue markets need not occur solely because of swings in GDP. That is, a window of opportunity could occur in any period in which the cost of issuing equity is lower for all firms, such as when events known by both managers and

\footnotetext{
${ }^{3}$ This model can also generate hot markets through variation in the cost of evaluating firms' prospects, but the authors emphasize the change in profitability as a more natural explanation for hot markets.

${ }^{4}$ Korajczyk, Lucas and McDonald (1991) also have a model to explain the timing of equity issuance that is based on time-varying asymmetric information, but it mostly refers to timing of individual firms' offerings based on the time lapse between firms' earnings announcements.
} 
investors dominate firm-specific information. As in Choe et al., a hot market is characterized by a smaller lemons premium, leading to less negative SEO announcement effects on average. Thus, they too predict that hot market issuers are expected to be better quality firms on average.

Firms in the Lucas and McDonald (1990) model also face asymmetric information problems, but they may delay their equity offerings if their stocks are undervalued. In contrast, overvalued firms prefer to issue immediately, lest the stock price falls. Lucas and McDonald show that a large number of random positive draws from the pricing distribution is sufficient for an increase in equity issuance -- there need not be any fundamental change in the firms' operations or the distribution of pricing errors for waves of equity issuance to occur. Their model implies that an upswing in the number of IPOs reflects incentives for a greater fraction of better quality firms to raise equity.

\section{B. Empiricai Evidence on Hot and Cold Markets}

The empirical evidence on the quality of firms that issue equity in hot and cold markets is mixed. Choe et al. and Bayless and Chaplinsky find that the stock market reactions to announcements of equity offerings are less negative in hot markets, as their theories predict. The two studies' results differ mainly in how they define hot markets - Choe et al. analyze variations in stock returns according to the business cycle, which is quite similar to the equity issuance (or IPO) cycle, while Bayless and Chaplinsky define their markets by volume of offerings. Thus, their evidence is consistent with the asymmetric information theories' view that hot market issuers are better firms.

Empirical tests of IPO signaling models are less supportive of the asymmetric information view. Jegadeesh et al. find that, while subsequent equity issuance patterns are consistent with signaling theories, underpricing does not appear to play a strong signaling role for IPOs. Spiess and Pettway show that the losses involved in underpricing are not justified by subsequent stock price improvements for seasoned offerings. Michaely and Shaw find no evidence in support of the signaling theories in their analysis of master limited partnerships.

In sharp contrast to the examination of announcement effects of SEOs, studies of the long-run stock performance of IPOs and SEOs suggests that hot market equity issuers are inferior firms. Ritter (1991), Spiess and Affleck-Graves (1995) and Loughran and Ritter (1995) find that 
the stocks of equity issuers severely lag the returns on a wide variety of benchmarks, and Loughran and Ritter note that returns are sharply lower among firms that offered equity in hot markets. They regress cross-section returns on an indicator of a hot market and find an average returñ that is 43 basis points lower than that for cold markets. And, although hot markets typically involve greater initial stock returns for IPOs, they find the underperformance of IPOs is not offset by high initial returns. Loughran and Ritter conclude that hot market equity offerings are made by lower quality firms who knowingly take advantage of investor overoptimism.

Jain and Ǩini (1994) and Mikkel̄son and Shah (1994) do not specifically study hot markets in comparison to cold markets, but their results based on accounting data indicate that IPO firms time their offerings to coincide with peak operating performance. Both studies find evidence of sharp declines in operating performance once public. Jain and Kini find that operating ROAs and operating cash flow to assets fall between the pre-IPO year and each of the four subsequent years examined thereafter. Mikkelson and Shah report similar results over a longer sample period - up to ten years after the IPO - and that lower stock returns tend to occur in firms with sharper declines in earnings. Loughran and Ritter (1994) find similarly poor operating performance for SEO firms. These results provide indirect evidence that hot market equity issuers are worse firms than cold market firms.

Teoh, Wong, and Rao (1994) examine the use of discretionary accruals in accounting at the time of the IPO and find evidence of managerial opportunism. They report weak evidence that these accruals are higher among hot market IPOs.

Cheng (1995) suggests that stock price underperformance is related to the subsequent use of SEO proceeds - firms that do not spend the funds on capital expenditures have worse longterm performance. This is also suggestive of managerial opportunism in hot markets, although he does not specifically examine hot and cold market issuers.

Lerner (1994) al̃so provides evidence that firms take advantage of windows of opportunity to issue equity. In his investigation of a group of biotechnology firms that received funds from venture capitalists, he concludes that their IPOs are timed to coincide with peaks in public market prices.

Although the evidence on stock underperformance points to hot market issuers as the 
main culprit in the group of equity issuers, the indirect evidence on the relationship between hot market issuers and operating performance often fails to confirm such a pessimistic view of hot market IPOs. In particular, Jain and Kini find no relationship between operating performance and IPO underpricing, which is higher in hot markets; nor do Mikkelson and Shah find a particularly strong relationship between operating performance and the year in which the firm went public. Our study provides direct evidence linking firm quality and IPO cycles.

\section{Data}

Our analysis of hot and cold markets compares firms that went public in 1983, which was an extraordinarily hot year, with firms that completed IPOs in 1988, a cold market year for IPOs. We choose these two years because they are both recent enough that financial data are broadly available, but not so recent that we could not evaluate the firms over five years. Based on the number of nonfinancial IPOs since 1980, shown in Table 1, these two years seem appropriate. The highest issuance since 1980 was in 1983. Issuance remained moderate to heavy through 1987. In 1988-1990, the number of IPOs each year dropped off sharply. Of these cold market years, 1988 was the one for which five years of data on operating results were available. ${ }^{5}$ Additionally, the 1988 market, while cold, provides a slightly larger sample for analysis than the 1989 market. We also note that Loughran and Ritter (1995) describe the period between the crash of October 1987 and the Gulf War victory in February 1991 as a period of low equity issuance. Moreover, these two years are close enough chronologically that the IPOs are likely to be drawn from the same quality distributions.

Our samples of 1983 and 1988 IPOs include all nonfinancial firms that completed IPOs in those years according to Securities Data Company (SDC). We restrict our analysis to firmcommitment offerings of $\$ 2.5$ million or more that are not reverse leveraged buyouts, spinoffs, or

\footnotetext{
${ }^{5}$ In contrast, Bayless and Chaplinsky count April to September 1988 among their hot market periods. They classify their periods according to the ranking of the monthly issuance listed in the Federal Reserve Board's Annual Statistical Digest. The Digest records the dollar volume of common and preferred equity raised by all U.S. firms. The equity raised in 1988 includes a large amount of offerings by closed-end investment companies, without which the period would have been characterized as cold.
} 
unit offerings. In addition, we only examine firms whose offering share price exceeded $\$ 1$. Financial data were obtained from Compustat for most firms, supplemented by data from Compact Disclosure when Compustat data were unavailable.

Stock price data were obtained from the Center for Research on Security Prices (CRSP). Several of the firms identified in the SDC dataset are not followed by CRSP. Data for others are questionable - the first price observation is months after the IPO or weeks before; the first trading price is less than $\$ 1$ even though SDC indicates an offering price closer to $\$ 5$. After eliminating these observations, the samples for 1983 and 1988 included 263 and 84 observations, respectively.

Following Loughran and Ritter, we calculate returns from two weeks after the IPO to more closely replicate returns to a typical investor who may not be allocated shares in the IPO. Returns are calculated as the percentage difference in the price on two days, adjusted for splits and distributions. Our focus is on returns from two weeks after the IPO date until one, three and five years later. The returns distributions are highly skewed, so we avoid t-tests of means. Instead, our analysis focuses on the wealth relative, as in Loughran and Ritter.

The descriptive statistics in Table 2 show that traditional indicators of a hot market hold for the 1983 sample, but are not present in the 1988 sample. Underpricing averaged 14.6 percent for the 1983 IPOs and only 6.6 percent for the 1988 sample. IPO proceeds were smaller in the earlier year, reflecting the smaller average size of the 1983 firms. These differences in size are not attributable solely to inflation. ${ }^{6}$ Lastly, suggestive of more frequent oversubscription, the 1983 sample raised proportionately more funds in their IPOs.

Table 3 provides long-term stock performance measures for the 1983 and 1988 samples. To calculate the stock returns in Table 3, we keep firms that delist in the sample for as long as they trade. For each stock that does not include a full observation period (1, 3 or 5 years), we include an observation for the same period for the NASDAQ benchmark. For example, an IPO completed in January that trades until April will have a NASDAQ observation from January to April. As in previous research on long-term underperformance, the hot market IPO stocks have

${ }^{6}$ The CPI shows an increase in the price level of about 25 percent over this period. 
much lower wealth relatives than the cold market IPOs, measured by returns for 1,3 , and 5 years. The 1988 group often does at least as well as the NASDAQ. Considering the risk of the IPOs, however, the excess return over the NASDAQ return may not be sufficient for the 1988 IPOs. We note that returns for this group are quite strong in year five, but extremely sensitive to the inclusion of one stock - American Power Conversion Corporation (APCC). Without APCC, the wealth relative for the 1988 sample drops to .91 . These data indicate, contrary to the asymmetric information theories, that hot market IPO firms are inferior companies to those that go public in cold markets.

\section{Relative Performance of Hot and Cold Market IPO Firms}

We begin by describing the types of firms that go public in each market using information on the distribution of firms by industry and accounting data from the year of the IPO. We next consider the post-IPO performance of the hot and cold market IPO firms. If asymmetric information theory is correct, the firms that go public in hot years should eventually prove to be more successful firms than the cold market firms that did not feel they were undervalued. We also compare this accounting data to stock returns over similar time periods to determine if stock prices are reflecting a drop in performance as the managerial opportunism theory suggests. Lastly, we repeat the analysis after making an adjustment for survivorship bias.

\section{A. Firm Characteristics in the IPO Year}

Asymmetric information theories of IPOs often describe hot markets as periods when productivity shocks or technological advances occur in a particular industry, suggesting a greater industry concentration in hot markets. Table 4 presents the industry distributions of the 1983 and 1988 IPO firms according to 2-digit SIC codes. The distribution by industry of the 1983 firms is extraordinarily concentrated: four industries account for more than half of the sample. The 1988 sample, however, is only slightly more disperse: for example, while the top five SIC categories represent 57 percent of the 1983 sample, they account for 42 percent of the sample in 1988; the top eight industries represent 67 percent of the 1983 firms, compared to 57 percent of the 1988 sample. While these data suggest that hot markets are related to industry-specific shocks, consistent with the asymmetric information models, the cold market industry distribution is also 
fairly concentrated.

Less compelling for these models is the fact that the five most frequent industries are identical in both the hot and cold markets. That is, firms in computer software (SIC 73) and hardware (SICs 35 and 36), advanced medical equipment (SIC 38), and biotechnology (SIC 28) accounted for a large fraction of the offerings in both 1983 and 1988. A $\chi^{2}$ test that the industry distributions are homogenous in the two years cannot be rejected at standard levels of significance.

The similarity of the two samples' industry distributions makes it easier to benchmark the expected performance of the hot market firms. If hot market issuers are alike in all respects to cold market issuers except in the pricing of their stock (such as in the Lucas and McDonald model) and the distribution of firms is unchanged in the five years between 1983 and 1988, then we can safely assume that the hot market firms of 1983 considered themselves to be better quality firms than the cold market firms of 1988 . Otherwise, they would have been found the offering prices of cold markets such as 1988 and 1982 acceptable and would have gone public earlier.

Next, we consider whether the financial characteristics of hot and cold market IPO firms are different around the time of the offering. Table 5 presents statistics for the two sets of firms at the end of their IPO years. We focus on medians because the distributions of these measures are often skewed. Moreover, both theories of IPO behavior refer to the typical firm in a hot market compared to that in a cold market. ${ }^{7}$ To control for differences that arise because hot and cold markets typically occur at different points in the business cycle, we also compare the IPOs to other firms in their industries. Industry-adjusted measures compare firm values to the median value for firms in the same four-digit SIC category if the four-digit industry sample had more than 15 firms during the five years following the IPO year. If the four-digit SIC category did not have a sufficient sample size, the firm was matched to the three- or two-digit SIC category.

Firms that issued in 1983 were smaller than firms that issued in 1988, and considerably

\footnotetext{
${ }^{7}$ In contrast, analysis of long-term stock performance clearly requires the use of means to calculate wealth relatives. This creates an unfortunate barrier in the linkage of operating performance to stock performance.
} 
smaller than their industry counterparts. The 1988 IPO firms are also smaller than other firms in the industry, so that the two samples' sizes are not significantly different on an industry-adjusted basis. This evidence provides slight support for Chemmanur and Fulghieri's view that hot markets are characterized by firms that choose to go public earlier, presumably when they are smaller. The differences in size do not support the Lucas and McDonald view that firms wait for a price run-up before issuing equity, since firms in hot markets should be larger because they grew while waiting to go public.

Operating income (earnings before interest, taxes, depreciation and amortization), scaled either by assets or sales, is somewhat lower for the hot market firms, but only income scaled by assets differs significantly across the samples. Industry-adjusted measures of profitability are significantly lower for the hot market firms. This evidence contradicts the asymmetric information models, which predict that hot market issuers will be better firms.

It is possible that these hot market firms, though smaller and less profitable, are superior in that they have greater growth potential than cold market firms. However, investment opportunities, as measured by the ratio of capital expenditures-to-assets, are similar in the two sets of IPO firms. Industry-adjusted capital expenditures are significantly positive, but do not differ between the hot and cold market firms. Likewise, the degree of fixed assets, often interpreted as the inverse of growth opportunities, does not differ significantly between the two samples. The fraction of firms paying dividends is significantly higher in the 1988 sample, although the median for both samples is zero. The similarities in growth opportunities for the two sets of firms are contrary to the prediction of the asymmetric information models, such as Choe et al., in which the greater need for investment funds spurs equity issuance in hot markets. These results also fail to tie Cheng's results on low capital expenditures and long-term underperformance to hot markets.

Debt-to-asset ratios do not indicate substantial differences between the two samples of firms, as both sets of IPOs have very modest debt-to-asset ratios.

\section{B. Performance in Subsequent Years}

Asymmetric information theory suggests that the quality of hot and cold market firms is difficult to differentiate at the time of the offering except through the underpricing signal. 
However, a cornerstone of this theory is that the information about the firms' quality eventually becomes public knowledge, making the signaling behavior worthwhile. Thus, if asymmetric information drives the IPO timing decision, hot market IPO firms should eventually outperform the cold market firms. To analyze growth patterns after the IPO we look at two measures: first, we examine the industry-adjusted medians of the hot and cold market firms for up to five years after their respective IPOs; second, we investigate the median industry-adjusted year-over-year growth rates for the two groups.

Table 6 shows medians of operating measures for one, three and five years after the IPO. Rather than greater deterioration among the hot market IPOs, the differences between the two sets of firms are less marked over time. Profit ratios in the years after the IPO reveal little difference between the IPO firms and other firms in the same industry, and little difference between hot and cold market firms. Only for the 1983 IPO firms in year one is the median ratio of operating income-to-assets significantly below that of the typical firm in the industry and below that for the 1988 firms.

Likewise, the figures for capital expenditures do not differ significantly between the two sets of firms, as both samples mostly outspend their industry competitors.

Only sales differ significantiy between the hot and cold market firms: the 1988 firms grow to be larger than their typical competitors by the fifth year after the IPO, making them significantly larger than the 1983 IPOs by then.

Table 7 presents an alternative way of examining the post-IPO performance. The medians of year-over-year growth rates in this table also indicate that the two sets of IPO firms are quite similar. Changes in profit margins do not differ sharply between them; nor does sales growth diverge significantly. Capital expenditures grow at about the same pace for hot and cold market IPO firms, adjusted for industry growth.

Overall, these results on operating performance after the IPO contradict the asymmetric information models: We find little evidence that hot market IPO firms eventually reveal themselves to be of higher quality than cold market IPO firms. Post-IPO performance also allows us to examine the managerial opportunism view put forth by Jain and Kini and Loughran and Ritter, who argue that hot market IPOs time their offerings to take advantage of their best 
accounting reports, making the IPO year more likely to be the most profitable. Thus, managerial opportunism implies that hot market issuers will experience greater deterioration in profitability after the IPO. While the decline in profit margins in year one provide some support for the notion that opportunistic managers take their companies public in their peak year of performance, profit margins are maintained at levels similar to their industry counterparts for five years after the IPO. Further, there is no evidence that profit margins for hot market IPOs fall faster than the cold market IPOs'.

How did the stock market view these firms' prospects? Table 8 shows wealth relatives for the 1983 and 1988 firms for time periods that are similar to those shown in the tables 6 and 7 that use accounting data. The calculation of these returns assumes that the portfolios are rebalanced yearly - firms that delist prior to the beginning of a year are not included in that period's returns, just as firms without Compustat data in years three and five are excluded from the analysis in Tables 6 and 7 for those years. The wealth relatives in Table 8 show that both hot and cold IPOs underperform the market in the first full calendar year after going public, and the wealth relative is quite a bit lower for the 1983 firms. Both sets of IPO firms match the NASDAQ performance in subsequent years, but the 1988 IPOs have much higher wealth relatives. This owes partly to the performance of one firm - APCC - that has returns in excess of 1000 percent in years four and five. Without APCC, the hot and cold market IPOs' wealth relatives are quite similar in year five.

While accounting measures may not exactly a firm's value, the stock price results in Table 8 largely agree with the operating results presented in Table 5, 6 and 7: the greater sales and profit margins for the 1988 firms in year one might justify somewhat greater wealth relatives in the first couple of years. The lack of distinction in profit margins between the hot and cold market firms in later years is consistent with reduced differentiation in stock returns. These stock price results, however, do not support the asymmetric information models, as these models predict superior or equal performance (if signaling is complete) of hot market issuers relative to IPO firms in cold markets.

\section{Post-IPO performance adjusted for survivorship bias}

The stock returns in Table 8 are quite different from those presented in Table 3, which 
show underperformance on average for both samples and particularly poor returns for the hot market IPOs. There are several differences between the calculations of the wealth relatives in the two tables, but the main one is that the returns in Table 8 reflect only returns of firms that survived. Firms drop out of the Compustat and CRSP samples because of bankruptcies and mergers. If the nonsurvivors are evenly split between underperformers and successful firms, the results shown in the previous table will be unbiased. Delisting reasons on Compustat suggest that roughly half of the attrition in each sample owes to bankruptcies and half to mergers, suggesting the data are unbiased, but the difference in stock returns between Tables 3 and 8 suggest otherwise.

To correct for possible survivorship bias, we investigate the two sets of IPO firms while keeping incomplete data in the analysis. For operating performance, we include the latest operating results for firms that exit the sample prematurely. Thus, for example, the median sales growth figure for year five will be based mainly on growth from year four to five, but will also be based on data for nonsurviving firms from earlier years.

Tables 9 and 10 present measures of operating performance for the two IPO samples when data for nonsurvivors are used in the calculations. Both the hot and cold market firms look marginally worse in Table 9 when nonsurvivors are used in the calculations. Nevertheless, most of the profit measures remain insignificantly different from the median of the industry and the adjustment fails to differentiate the samples. While industry-adjusted sales fall slightly for both sets of firms, the nonsurvivors in the 1983 sample are much smaller, making the samples significantly different by size. Growth rates in Table 10 also are similar to those reported in Table 7. The growth rate of capital expenditures appears to be below the industry average later in the sample period for both sets of firms. We note, however, that both sets of firms invested much more than their industry counterparts in the early years of the IPO (see Tables 5 and 6).

Stock returns for the calendar periods comparable to the accounting data periods for these firms are presented in Table 11. The stock returns, similar to those in Table 3 except for the time periods, indicate severe underperformance among the 1983 IPOs, while the 1988 IPOs never do as badly and actually sharply exceed the benchmark returns if the investor is lucky enough to have APCC in his portfolio. Although adjusting for survivorship bias affects the wealth relatives 
sharply, this adjustment has little effect on the results on operating performance, thus severing the links between operating performance and stock returns. Neither the stock return data nor the accounting data suggest that hot market IPOs are superior firms, as the asymmetric information models predict. However, there is also little information in these accounting data that suggests hot market IPO firms are much worse, as Loughran and Ritter's stock price data imply. ${ }^{8}$

\section{Comparison of 1983 IPOs with 1982 Cold Market IPOs}

We have compared the 1983 hot market firms with the 1988 cold market firms on the assumption that firms in both years are drawn from the same quality distribution. That is, we assume that the hot market IPOs of 1983 passed up the opportunity to go public in 1982 (a cold market) because they would have been priced as cold market firms, reflecting the quality observed in 1982 and 1988. It is possible, however, that IPO firms in 1988 may differ from those in the early 1980s for reasons unrelated to hot and cold markets. Thus, in this section, we compare the operating performance of the 1983 IPO firms to the 1982 firms. The asymmetric information models would predict that firms that completed IPOs in 1982 considered themselves to be fairly valued or overvalued in that market, while firms that went public in 1983 waited for more favorable pricing or had a positive shock to expected profitability.

As we did for the 1983 and 1988 samples, we identified IPOs completed in 1982 using data from SDC and eliminated offerings that were too small or had offer prices of $\$ 1$ or less. Reflecting the cold market, the 1982 sample had only 43 firms. ${ }^{9}$ Similar to the 1983 and 1988 samples, more firms were in the computer software industry (SIC 73) than in any other, and computer hardware (SIC 35) and electronic components (SIC 36) each accounted for about 10 percent of the firms.

${ }^{8}$ Because underpricing is more severe for hot market IPOs, it is possible that their initial returns offset their subsequent poor returns to make them comparable to cold market IPOs, or the NASDAQ. We investigated this possibility and found that the wealth relatives for the 1983 based on the offer price were still below one and still lower than the 1988 firms' wealth relatives based on offer prices.

${ }^{9}$ Compustat data were available for 60 percent of the nonfinancial firms (excluding spinoffs) that completed IPOs in 1982, roughly the same as the 62 percent of IPO firms in 1983. 
Table 12 presents operating performance measures for the 1982 and 1983 firms. On an industry-adjusted basis, the 1982 and 1983 firms have about equivalent sales and capital expenditures-to-assets ratios at the time they go public. However, as with the 1988 firms, the 1982 firms are substantially more profitable than firms that went public in 1983. This evidence is at odds with the asymmetric information view that better quality firms wait to issue.

Nor do we find in the years following the IPO that the 1983 firms eventually outperform the cold market firms. In the first year after the IPO, operating margins for the 1982 firms fall, as they did for the other samples, but remain higher than margins for the 1983 firms. By the fifth year, they may be somewhat more profitable, but mostly performance is indistinguishable. Particularly, sales growth and capital expenditures for the 1982 and 1983 firms track rather closely out to year five. Thus, our examination of a set of IPO firms that are chronologically closer to the hot market issuers in 1983 indicate that there is no support for the asymmetric information model prediction that hot market issuers waited for more favorable pricing because of superior quality.

\section{Investor Sentiment and Stock Returns}

The wealth relatives of hot market IPOs fall short of the comparable figures for the cold market IPOs by most measures, yet our evidence on operating results do not indicate such strong differences between the two sets of firms. In this section we investigate whether investor sentiment can explain this apparent disconnection between stock returns and operating performance. To do so, we form portfolios of stocks based on very similar operating performance, calculate the wealth relatives of these portfolios, and examine whether they differ for the 1983 and 1988 samples of IPO firms.

In particular, we partition the combined group of 1983 and 1988 IPO firms into quartiles based on alternative performance measures -- industry-adjusted sales growth, profit growth, and growth in capital expenditures. Based on the values for each measure in each time period that defines the top and bottom quartiles for the combined group, we form portfolios of the best and worst performing firms in the 1983 and 1988 samples separately, and report their wealth relatives

in Table 13. If investor sentiment is the same for good firms in both hot and cold markets, then 
the wealth relatives for these portfolios of similar firms should not vary with the year in which they went public. If hot market firms are valued more than cold market firms of similar quality at issuance, then the long term performance should be worse for the hot market firms as their prices eventualily decline to those of comparable firms that went public in cold years. We note that there are no significant differences in the proportions that each IPO sample contributes to the best and worst groups - it is not the case that the best IPOs contain more 1988 firms nor that the worst groups have a disproportionate number of 1983 IPO firms.

The wealth relatives for the best and worst performing firms in Table 13 indicate a strong positive correlation between stock returns and growth in profitability. The firms that were in the top quartile for profit margin growth ended the first calendar year with wealth relatives of .95 and 1.17 for the 1983 and 1988 samples, respectively, while those in the lowest quartile only reported wealth relatives of .56 and .81 , respectively. Firms with the lowest long-term profit margins (years three and five) had extremely low wealth relatives. Profits scaled by assets were also a strong indication of stock returns - wealth relatives for the firms in the highest quartile of profitsto-assets were often more than double those of the firms in the lowest quartile. Similarly, firms in the top categories for investment growth had higher wealth relatives than their counterparts in the lowest quartile. We do not find, however, that high sales growth is associated with high stock returns.

A comparison of the wealth relatives of firms that went public in 1983 with those that went public in 1988, shown in Table 13, indicates that investor sentiment differs greatly across the two periods. Portfolios of firms based on the same minimum level of profit growth show that the 1988 IPO firms had much higher wealth relatives than highly profitable firms that went public in 1983. Among the worst performing firms, differences in pricing also tend to favor the cold market firms, although the differences based on operating income-to-assets are slight.

Similarly, firms with very rapid growth in capital expenditures had higher wealth relative if they came public in 1988 - IPO firms with equally high investments that went public in 1983 typically had lower stock returns. Among the low investment portfolios, the stock returns of the 1983 IPOs were inferior.

Although strong sales does not appear to be highly valued in all periods, even among the 
portfolios based on sales growth, the cold market firms of similar caliber always have superior stock returns.

These results suggest that investor sentiment in hot markets may have led to prices in 1983 that were bid up too high. For otherwise comparable performance in the years following the IPO, higher prices would lead to lower wealth relatives as investors cooled off to the hot market investments. Such a relationship between bid-up prices and lower returns is also documented for private venture capital investments in the early 1980s that led to very poor longrun returns (Fenn, Liang and Prowse (1995)). These results are also reminiscent of differences between value and glamour stocks pointed out by Lakonishok, Shleifer and Vishney (1994).

\section{Conclusions}

In this study we examine the quality of IPO firms in hot and cold markets to determine if hot equity markets draw in better firms, as suggested by IPO signaling modeils, or if hot markets are characterized by managerial opportunism combined with investor irrationality, as Loughran and Ritter suggest. Using a sample of 1983 hot market IPOs and a sample of 1988 cold market IPOs, we investigate the characteristics of the firms around the time of the IPO and their subsequent profitability and growth. Then, we link stock returns of these firms to their operating performance.

At the time of the IPO, the hot market firms appear to be less profitable than cold market firms, and have lower sales, but not when sales are adjusted for typical levels in the industry. Other characteristics, such as the distribution of firms by industry, investment opportunities and leverage, are similar for the hot and cold market firms in the IPO year. This evidence is inconsistent with the asymmetric information theories as there is no indication that hot market IPO firms are superior. Furthermore, the 1983 IPO firms' stocks underperform the NASDAQ over the first year of trading, although they typically have higher profits and more investment opportunities than other firms in their industries.

Data on operating performance in the five years after the IPO provide scant evidence of differences in firm quality over the IPO cycle. For most of the sample period there is no significant difference in operating income to sales or asset between the hot and cold market 
issuers. The only significant difference between the two sets of firms is their size - by the end of the fifth year the cold market firms are significantly larger. Nor is there much evidence that these firms are worse than their industry counterparts in the post-IPO years. The lack of distinction between hot and cold market issuers is reinforced by our investigation of firms that completed IPOs in the cold market of 1982.

Because many IPO firms drop out of the sample we examine whether differences in survivorship rates can explain our results. Nonsurvivors do not appreciably affect the distribution of profitability, growth or investment measures, although the 1983 nonsurvivors are especially small. Stock returns, however, are substantially worse for the 1983 firms when nonsurvivors are included in the sample.

The fact that nonsurvivors reduce the wealth relatives of the 1983 sample much more than they reduce profitability suggests that firms with identical characteristics may have experienced wildly divergent stock returns depending on when they came public. We further investigate this issue by examining the best and worst performing firms in the two samples and find that similar firms have much higher wealth relatives if they go public in a cold market. This may reflect excessively high prices at the time of the IPO, such that subsequent returns reflect corrections to these bid-up prices.

Our evidence shows that the long-run operating performance of hot and cold market issuers does not differ substantially in the five years following the IPO. Thus, we find no evidence in favor of the asymmetric information theories of equity issuance cycles that hot markets are characterized by better firms. At the same time, our evidence does not support the view of the stock price underperformance literature that hot market issuers are low quality firms with opportunistic managers. We find some evidence that pricing is affected by overoptimism in hot markets - the wealth relatives for firms of similar caliber are typically lower for hot market firms, suggesting a decline from unsustainably high prices immediately following the IPO. 


\section{REFERENCES}

Allen, F. And G. Faulhaber (1989) "Signaling by Underpricing in the IPO Market," Journal of Financial Economics, 23, 303-323.

Bayless, M. And S. Chaplinsky (1996) "Is There a Window of Opportunity for Seasoned Equity Issuance?," Journal of Finance, 50, 253-278.

Chemmanur, T. and P. Fulghieri (1995) "A Theory of the Going-Public Decision," unpublished paper, Columbia University and INSEAD.

Cheng, L. (1995) "Equity Issue Under-Performance and the Timing of Security Offerings," unpublished paper, MIT.

Choe, H., R. Masulis, and V. Nanda (1993) "Common Stock Offerings across the Business Cycle," Journal of Empirical Finance, 1, 1-29.

Fenn, G., N. Liang, and S. Prowse (1995) "The Economics of the Private Equity Market," Staff Study of the Board of Governors of the Federal Reserve System \#168.

Grinblatt, M. and C. Hwang (1989) "Signaling and the Pricing of New Issues," Journal of Finance, 44, 393-420.

Ibbotson, R. and J. Jaffe (1975) "Hot Issue Markets," Journal of Finance, 30, 1027-1042.

Jain, B. and O. Kini (1994) "The Post-Issue Operating Performance of IPO Firms," Journal of Finance, 49, 1699-1726.

Jegadeesh, N., M. Weinstein, and I. Weich, "An Empirical Investigation of IPO Returns and Subsequent Equity Offerings," Journal of Financial Economics, 34, 153-175.

Korajczyk, R., D. Lucas, and R. McDonald (1991) "The Effect of Information Releases on the Pricing and Timing of Security Issues," Review of Financial Studies, 4, 685-708.

Lakonishok, J., A. Shleifer and R. Vishney (1994) "Contrarian Investment, extrapolation, and Risk," Journal of Finance, 49, 1541-1578.

Lerner, J. (1994) "Venture Capitalists and the Decision to Go Public," Journal of Financial Economics, 35, 293-316.

Loughran, T. and J. Ritter (1994) "The Operating Performance of Firms Conducting Seasoned Equity Offerings," unpublished paper, University of Iowa and University of Illinois at Urbana-Champaign. 
(1995) "The New Issues Puzzle," Journal of Finance, 50, 23-51.

Lucas, D. and R. McDonald (1990) "Equity Issues and Stock Price Dynamics," Journal of Finance, 45, 1019-1043.

Michaely, R. and W. Shaw (1994) "The Pricing of Initial Public Offerings: Tests of AdverseSelection and Signaling Theories," The Review of Financial Studies, 7, 279-319.

Mikkelson, W. and K. Shah (1994) "Performance of Companies Around Initial Public Offerings," unpublished paper, University of Oregon and Auckland University.

Ritter, J. (1984) "The 'Hot Issue' Market of 1980," Journal of Business, 57, 215-240.

46, 3-27.

(1991) "The Long-Run Performance of Initial Public Offerings," Jourmal of Finance,

Spiess, K. and J. Affleck-Graves (1995) "The Long-Run Performance of Following Seasoned Public Offerings," Journal of Financial Economics.

Spiess, K. and R. Pettway (1995) "The IPO and First Seasoned Equity Sale: Issue Proceeds, Owner/Managers' Wealth, and the Underpricing Signal," unpublished manuscript, University of Notre Dame and University of Missouri.

Teoh, S., Wong, T., and G. Rao (1994) "Incentives and Opportunities for Earnings Management in İitial Public Offerings," unpublished manuscript, U. Michigan, U. Maryland and Fidelity Management and Research Co.

Welch, I (1989) "Seasoned Offerings, Imitation Costs, and the Underpricing of Initial Public Offerings," Journal of Finance, 44, 421-449. 
Table 1

\begin{tabular}{|lcc|}
\hline \multicolumn{3}{|c|}{ IPO Issuance by Year* } \\
\hline & Number of IPOs & $\begin{array}{c}\text { Gross Proceeds } \\
\text { (\$billions) }\end{array}$ \\
\cline { 2 - 3 } 1980 & 129 & 0.83 \\
1981 & 321 & 2.04 \\
1982 & 110 & 0.99 \\
1983 & 575 & 7.19 \\
1984 & 287 & 2.24 \\
1985 & 262 & 3.09 \\
1986 & 506 & 10.22 \\
1987 & 400 & 9.73 \\
1988 & 162 & 3.84 \\
1989 & 174 & 3.56 \\
1990 & 146 & 3.38 \\
1991 & 322 & 12.84 \\
1992 & 426 & 17.25 \\
1993 & 536 & 19.45 \\
1994 & 463 & 13.65 \\
\hline Source: Securities Data Company. & \\
\hline Includes PO issuance by nonfinancial domestic companies. \\
\hline
\end{tabular}


Table 2

\section{Proceeds and Size of Firms that Issued IPOs in 1983 and 1988}

Table values are mean (median) values for IPO firms in 1983 and 1988. IPO amount is from Securities Data Company (SDC). Sales are 1983 and 1988 values from COMPUSTAT. One-day returns are calculated as the percent difference between offer price from SDC and the closing price on the first day of trading from CRSP. Significance tests for differences in mean values are based on F-statistics and tests for differences in median values are based on the Wilcoxon two-sample ranked sum test.

\begin{tabular}{|c|c|c|c|}
\hline & \multicolumn{2}{|c|}{ Ýear of IPO } & \multirow[b]{2}{*}{ Test Statistic } \\
\hline & 1983 & 1988 & \\
\hline \multirow[t]{2}{*}{ One-day Return (\%) } & 14.6 & 6.6 & $2.86 * * *$ \\
\hline & $(3.9)$ & $(3.8)$ & -1.00 \\
\hline \multirow[t]{2}{*}{ IPO Amount (\$mill) } & 13.6 & 19.3 & $2.00 * * *$ \\
\hline & $(7.9)$ & $(10.8)$ & $2.57 * * *$ \\
\hline \multirow[t]{2}{*}{ Sales (\$mill) } & 53.3 & 119.9 & $2.32 * * *$ \\
\hline & $(18.0)$ & $(37.6)$ & $4.00 * * *$ \\
\hline \multirow[t]{2}{*}{ IPO Amouni-to-Sales $(\%)$} & 28.4 & 3.0 & $340.10 * * *$ \\
\hline & $(52.5)$ & $(29.4)$ & $-3.76 * * *$ \\
\hline Number of Firms & 258 & 84 & \\
\hline
\end{tabular}




\section{Table 3 \\ The Long Run Stock Returns of 1983 IPOs and 1988 IPOs}

The sample includes firms that completed IPOs in 1983 and 1988. Returns are calculated from CRSP daily share price data. Firms with missing or questionable data on CRSP are excluded from the sample. IPO retums $\left(r_{i}\right)$ are calculated using daily data (not compounded) from two weeks after tje IPO date to the last day of the 1st, 3rd, of 5th year after the IPO, where years are periods of 252 trading days. For each IPO, we calculate the return on the Nasdaq $\left(r_{n}\right)$ to for the same period, which may be less than a year if the firm delists. The means of each set of observations $\left(r_{i}\right.$ and $\left.r_{n}\right)$ are used to compute wealth relatives $\left(1+r_{i} / 1+r_{n}\right)$.

\begin{tabular}{|c|c|c|c|c|c|c|}
\hline \multirow[b]{2}{*}{ Return period } & \multicolumn{3}{|c|}{1983 IPOs } & \multicolumn{3}{|c|}{1988 IPOs } \\
\hline & $\begin{array}{l}\text { Mean } \\
\text { IPO } \\
\text { Return }\end{array}$ & $\begin{array}{l}\text { Mean } \\
\text { Nasdaq } \\
\text { Return } \\
\end{array}$ & $\begin{array}{l}\text { Wealth } \\
\text { Relative } \\
\end{array}$ & $\begin{array}{c}\text { Mean } \\
\text { IPO } \\
\text { Return }\end{array}$ & $\begin{array}{c}\text { Mean } \\
\text { Nasdaq } \\
\text { Return }\end{array}$ & $\begin{array}{l}\text { Wealth } \\
\text { Relative } \\
\end{array}$ \\
\hline $\begin{array}{l}\text { Listing to end of } \\
\text { one year }\end{array}$ & -24.0 & -16.2 & .91 & 20.4 & 16.0 & 1.04 \\
\hline $\begin{array}{l}\text { Listing to end of } \\
\text { three years }\end{array}$ & 4.8 & 22.9 & .85 & 40.5 & 26.7 & 1.11 \\
\hline $\begin{array}{l}\text { Listing to end of } \\
\text { five years }\end{array}$ & -7.3 & 24.7 & .74 & 127.9 & 66.0 & 1.37 \\
\hline Excluding APCC & - & - & - & 51.1 & 66.0 & .91 \\
\hline
\end{tabular}


Table 4

Industry Concentrations of Firms that issued IPOs in 1983 and 1988

A. Percent of IPO Firms in the Leading SIC Categories

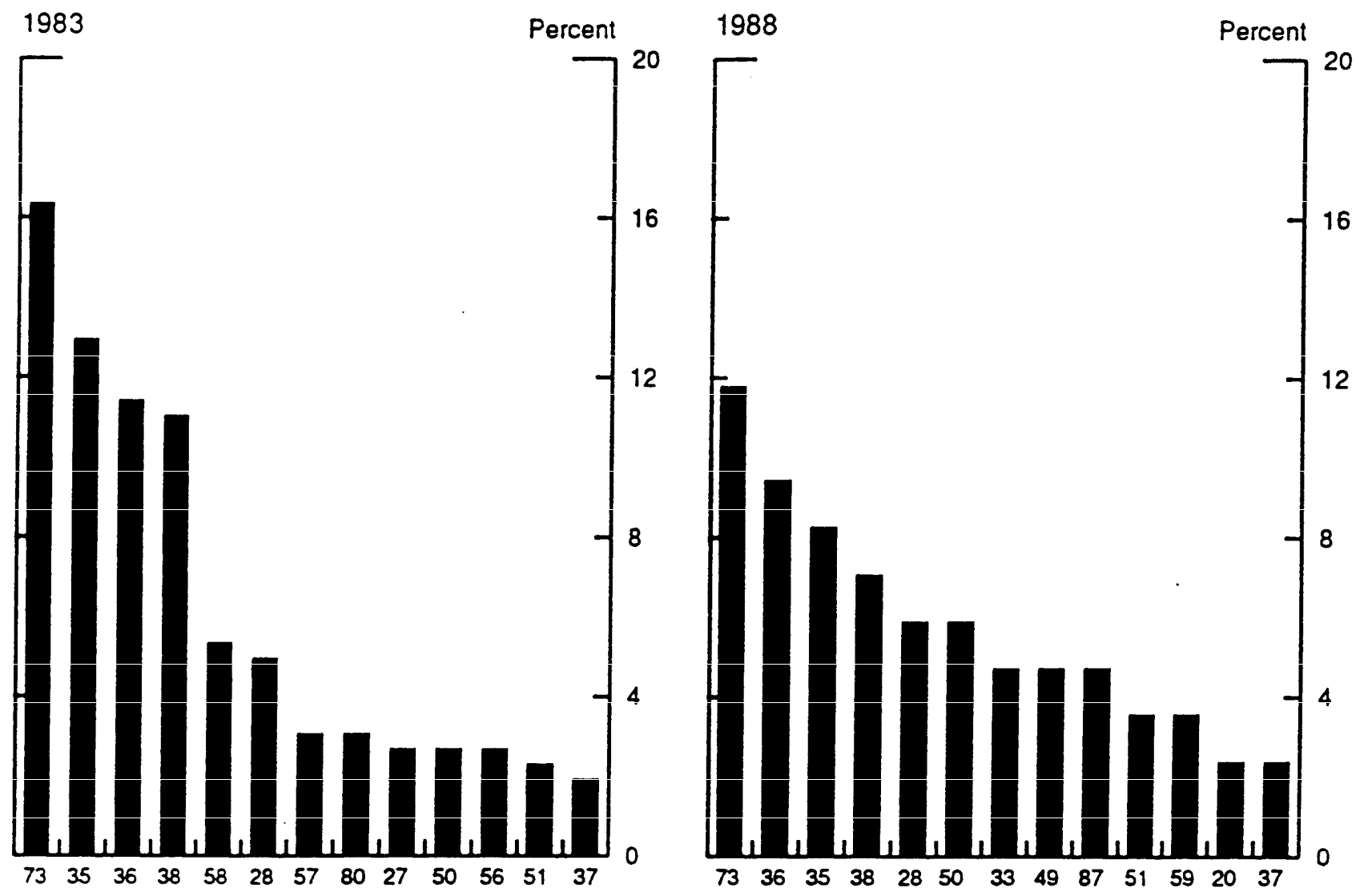

\begin{tabular}{|ccc|ccc|}
\hline \multicolumn{6}{|c|}{$\begin{array}{c}\text { B. Cumulative Percent of IPO Firms } \\
\text { in the Leading SIC Categories }\end{array}$} \\
\hline \multicolumn{7}{|c|}{ SIC } & 1983 & & \multicolumn{3}{c|}{1988} \\
Category & Percent & $\begin{array}{c}\text { Cumulative } \\
\text { Percent }\end{array}$ & $\begin{array}{c}\text { SIC } \\
\text { Category }\end{array}$ & Percent & $\begin{array}{c}\text { Cumulative } \\
\text { Percent }\end{array}$ \\
\hline 73 & 16.3 & 16.3 & 73 & 11.8 & 11.8 \\
35 & 12.9 & 29.2 & 36 & 9.4 & 21.2 \\
36 & 11.4 & 40.6 & 35 & 8.2 & 29.4 \\
38 & 11.0 & 51.6 & 38 & 7.1 & 36.5 \\
58 & 5.3 & 56.9 & 28 & 5.9 & 42.4 \\
Other & 43.1 & 100.0 & Other & 57.6 & 100.0 \\
\hline
\end{tabular}


Table 5

\section{Characteristics of Firms that Issued IPOs in 1983 and 1988}

Table values are the median values for IPO furms in 1983 and 1988. Data are 1983 and 1988 values from the COMPUSTAT research tapes. Operating income is operating income before depreciation; capital expenditures are for fixed plant and equipment and acquisitions; and debt is shor- and long-term debt. The significance iesis for differences in median values are based on the Wilcoxon two-sample ranked sum test.

\section{A. Firm Characteristics}

Sales (\$mill) Industry-Adjusted

Operating Income-to-Sales (\%) Industry-Adjusted

Operating Income-to-Assets (\%) Industry-Adjusted

Capital Exp.-to-Asset (\%) Industry-Adjusted

Debt-to-Assets (\%)

Fixed Assets-to-Assets (\%)

Dividends-to-lncome (\%)

\begin{tabular}{|c|c|c|}
\hline \multicolumn{2}{|c|}{ Year of IPO } & \multirow[b]{2}{*}{ Significance } \\
\hline 1983 & 1988 & \\
\hline 18.0 & 37.6 & $* * *$ \\
\hline$-52.8 \ldots$ & -35.6 & \\
\hline
\end{tabular}

10.5

12.5

$1.0+$ 3.9

13.1

0.6

16.8 $5.9 \cdots$

8.8

8.2

$3.3+$

$1.3+$

10.7

14.3

18.3

15.0

0.0

0.0

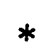

***

$* * *$

${ }^{* * *} .{ }^{* *} .{ }^{*}$ denote differences between 1983 and 1988 medians are significant at $1 \%, 5 \%$, and $10 \%$, respectively, based on a Wilcoxon two-sample ranked sum test.

${ }^{+++} .^{++}+$denote industry-adjusted medians are significantly different from zero at $1 \%, 5 \%$, and $10 \%$, respectively, based on a Wilcoxon signed rank test. 


\section{Table 6}

\section{Firm Characteristics in Years Following the IPO for Firms that Issued IPOs in 1983 and 1988}

Table values are industry-adjusted medians for IPO firms in 1983 and 1988. Median industry-adjusted sales is the median difference between firm sales and the median sales for firms in its industry as a percent of median sales for firms in its industry. Median industry-adjusted operating income ratios are the median difference between the firm value and the median value for firms in its industry. Operating income is operating income before depreciation, as defined on COMPUSTAT research tapes. Years 1-5 represent calendar years 1984-1988 for the 1983 IPO firms, and calendar years 1989-1993 for the 1988 IPO firms. Year values are based on firms remaining in the sample.

Op. Inc.-to-Sales (\%)

Op. Inc.-to-Assets (\%)

Cap. Exp.-to-Assets (\%)

\begin{tabular}{|c|c|c|c|c|}
\hline & \multicolumn{3}{|c|}{ Year After IPO } \\
\hline & & Year 1 & Year 3 & Year 5 \\
\hline Sales (\%) & $\begin{array}{l}1983 \text { IPO Firms } \\
1988 \text { IPO Firms } \\
\text { Significance }\end{array}$ & $\begin{array}{l}-35.0 \\
12.2 \\
* *\end{array}$ & $\begin{array}{r}6.3 \\
51.4\end{array}$ & $\begin{array}{l}4.0 \\
82.3^{+} \\
* *\end{array}$ \\
\hline Op. Inc.-to-Sales (\%) & $\begin{array}{l}1983 \text { IPO Firms } \\
1988 \text { PPO Firms } \\
\text { Significance }\end{array}$ & $\begin{array}{l}0.2 \\
1.3\end{array}$ & $\begin{array}{r}-0.5 \\
0.2\end{array}$ & $\begin{array}{r}-0.1 \\
0.6\end{array}$ \\
\hline Op. Inc.-to-Assets (\%) & $\begin{array}{l}1983 \text { IPO Firms } \\
1988 \text { IPO Firms } \\
\text { Significance }\end{array}$ & $\begin{array}{l}-1.3^{+} \\
1.9 \\
*\end{array}$ & $\begin{array}{r}0.3 \\
-0.2\end{array}$ & $\begin{array}{l}0.4 \\
1.5\end{array}$ \\
\hline Cap. Exp.-to-Assets (\%) & $\begin{array}{l}1983 \text { IPO Firms } \\
1988 \text { IPO Firms } \\
\text { Significance }\end{array}$ & $\begin{array}{l}4.0 \\
3.7\end{array}$ & $\begin{array}{l}1.0^{+} \\
1.8\end{array}$ & $\begin{array}{l}0.4 \\
1.1^{+}\end{array}$ \\
\hline
\end{tabular}


Table 7

\section{Median Annual Growth Rates of Firm Characteristics for Firms that Issued IPOs in 1983 and 1988}

Tahle values are industry-adjusted median growth rates for IPO firms in 1983 and 1988. Median industry-adjusted values are the median difference between the firm value and the median value for firms in its industry. Operating income is operating income before depreciation, as defined on COMPUSTAT research tapes. The years 1-5 represent calendar years 1984-1988 for the 1983 IPOs and calendar years 1989-1993 for the 1988 IPO firms. Year values are based on furms remaining in the sample.

\begin{tabular}{|c|c|c|c|c|}
\hline & & & Year Afte & \\
\hline & & Year 1 & Year 3 & Year 5 \\
\hline Growth in: & & & & \\
\hline Sales (\%) & 1983 IPO Firms & $21.5 \ldots$ & $4.4+$ & $2.9+$ \\
\hline & $\begin{array}{l}1988 \text { IPO Firms } \\
\text { Significance }\end{array}$ & $22.6 \ldots$ & 6.4 & 2.2 \\
\hline Op. Inc.-to-Sales (\%) & 1983 IPO Firms & $-0.8+$ & 0.5 & 0.5 \\
\hline & $\begin{array}{l}1988 \text { IPO Firms } \\
\text { Significance }\end{array}$ & $-1.3+$ & -0.7 & 0.5 \\
\hline Op. Inc.-to-Âssets (\%) & 1983 IPO Firms & $-2.5 \ldots$ & 1.4 & $0.8^{+}$ \\
\hline & $\begin{array}{l}1988 \text { IPO Firms } \\
\text { Significance }\end{array}$ & -2.2 & -1.0 & 1.0 \\
\hline Cap. Exp.-to-Assets (\%) & 1983 IPO Firms & $1.3 \omega$ & -0.6 & -0.1 \\
\hline & $\begin{array}{l}1988 \text { IPO Firms } \\
\text { Significance }\end{array}$ & 0.7 & -1.2 & -0.2 \\
\hline $\begin{array}{l}\text { F** }^{* * *},{ }^{*} \text { denote differences bet } \\
\text { based on a Wilcoxon two-sample } \\
+\cdots+.^{++}+{ }^{+} \text {denote medians are } \\
\text { Wilcoxon signed rank test. }\end{array}$ & $\begin{array}{l}83 \text { and } 1988 \text { media } \\
\text { sum test. } \\
\text { tly different from }\end{array}$ & $\begin{array}{l}\text { e signifi } \\
1 \%, 5\end{array}$ & $\begin{array}{l}1 \% .5 \% \text {. } \\
10 \% \text {, re }\end{array}$ & b. resp \\
\hline
\end{tabular}


Table 8

\section{Annual returns on 1983 and 1988 IPO stocks}

The sample includes firms that completed IPOs in 1983 and 1988. Returns are calculated from CRSP daily share price data. Firms with missing or questionable data on CRSP are excluded from the sample. IPO retums $\left(r_{i}\right)$ are calculated using daily data (not compounded) from the start of the year to the last day of the year for the first through fitth calendar years after the IPO date. Firms that delisted prior to the first day of the period reported are excluded from the calculation for that period. For each IPO, we calculate the return on the Nasdaq $\left(r_{n}\right)$ for the same period, which may be less than a year if the firm delists. The means of each set of observations $\left(r_{i}\right.$ and $\left.r_{n}\right)$ are used to compute wealth relatives $\left(1+r_{i} / 1+r_{n}\right)$.

\begin{tabular}{lccccc}
\hline & $\begin{array}{c}\text { First } \\
\text { year }\end{array}$ & $\begin{array}{c}\text { Second } \\
\text { year }\end{array}$ & $\begin{array}{c}\text { Third } \\
\text { year }\end{array}$ & $\begin{array}{c}\text { Fourth } \\
\text { year }\end{array}$ & $\begin{array}{c}\text { Fifth } \\
\text { year }\end{array}$ \\
\hline & & & & & \\
1983 IPOs & -22.5 & 32.2 & 16.9 & 5.9 & 58.0 \\
1983 Nasdaq & -11.0 & 30.5 & 7.8 & -5.2 & 12.3 \\
Wealth Relative & .87 & 1.01 & 1.09 & 1.12 & 1.41 \\
& & & & & 103.4 \\
1988 IPOs & 10.6 & -5.0 & 99.2 & 63.2 & 15.4 \\
1988 Nasdaq & 20.2 & -17.6 & 55.2 & 13.2 & 1.76 \\
Wealth Relative & .92 & 1.15 & 1.28 & 1.44 & 1.37 \\
Excluding APCC & .91 & 1.11 & 1.20 & 1.25 &
\end{tabular}


Table 9

\section{Firm Characteristics in Years Following the IPO for Firms that Issued IPOs in 1983 and 1988-Adjusted for Survivorship Bias}

Tahle values: are industry-adjusted medians for IPO furms in 1983 and 1988. Median industry-adjusted sales is the inedian difference between firm sales and the median sales for firms in its industry as a percent of median sales for firms in its industry. Median industry-adjusted operating income ratios are the median difference hetween the firm value and the median value for firms in its industry. Operating income is operating income heforc depriciation. as defined on COMPUSTAT research tapes. Years 1-5 represent calendar years 1984-1988 for the 1983 IPO firms, and calendar years 1989-1993 for the 1988 IPO firms. Year values include firms that fail or are acyuired and use the value of the last year the firm is in the sample.

\begin{tabular}{|c|c|c|c|c|}
\hline & \multicolumn{3}{|c|}{ Year After IPO } \\
\hline & & Year 1 & Year 3 & Year 5 \\
\hline Sales $(\%)$ & $\begin{array}{l}1983 \text { IPO Firms } \\
1988 \text { IPO Firms } \\
\text { Significance }\end{array}$ & $\begin{array}{l}-35.4 \ldots \\
9.7 \\
*\end{array}$ & $\begin{array}{c}-8.1 \\
48.0 \\
*\end{array}$ & $\begin{array}{l}-9.1 \\
82.3^{+} \\
* *\end{array}$ \\
\hline Op. Inc.-to-Sales (\%) & $\begin{array}{l}1983 \text { IPO Firms } \\
1988 \text { IPO Firms } \\
\text { Significance }\end{array}$ & $\begin{array}{l}0.3 \\
1.3\end{array}$ & $\begin{array}{r}-0.9 \\
0.2\end{array}$ & $\begin{array}{r}-1.0 \\
0.5\end{array}$ \\
\hline Op. Inc.-to-Assets (\%) & $\begin{array}{l}1983 \text { IPO Firms } \\
1988 \text { IPO Firms } \\
\text { Significance }\end{array}$ & $\begin{array}{c}-2.1 \\
1.6 \\
*\end{array}$ & $\begin{array}{l}-0.9 \\
-0.8\end{array}$ & $\begin{array}{r}-0.9 \\
0.8\end{array}$ \\
\hline Cap. Exp.-to-Assets (\%) & $\begin{array}{l}1983 \text { IPO Firms } \\
1988 \text { IPO Firms } \\
\text { Significance }\end{array}$ & $\begin{array}{l}4.1 \ldots \\
3.6\end{array}$ & $\begin{array}{l}1.0^{+} \\
1.8^{+}\end{array}$ & $\begin{array}{l}0.2 \\
1.1\end{array}$ \\
\hline \multicolumn{5}{|c|}{$\begin{array}{l}\text { ****** denote differences between } 1983 \text { and } 1988 \text { medians are significant at } 1 \%, 5 \% \text {, and } 10 \% \text {, respectively, } \\
\text { based on a Wilcoxon two-sample ranked sum test. } \\
\text { Wilcoxon signed rank test. }\end{array}$} \\
\hline
\end{tabular}




\section{Table 10}

\begin{tabular}{|c|c|c|c|c|}
\hline \multicolumn{5}{|l|}{$\begin{array}{l}\text { Median Annual } \\
\text { that Issued IPOs } \\
\text { Table values are industry-adjust } \\
\text { industry-adjusted values are the } \\
\text { industry. Operating income is or } \\
\text { tapes. The years } 1-5 \text { represent } c \\
\text { the } 1988 \text { IPO firms. Year values } \\
\text { firm is in the sample. }\end{array}$} \\
\hline & \multicolumn{3}{|c|}{ Year After IPO } \\
\hline & & Year 1 & Year 3 & Year 5 \\
\hline \multicolumn{5}{|l|}{ Growth in: } \\
\hline Sales (\%) & $\begin{array}{l}1983 \text { IPO Firms } \\
1988 \text { IPO Firms } \\
\text { Significance }\end{array}$ & $\begin{array}{l}21.5 \\
22.6\end{array}$ & $\begin{array}{l}5.1+ \\
6.4\end{array}$ & $\begin{array}{l}4.0^{+} \\
2.2\end{array}$ \\
\hline Op. Inc.-to-Sales (\%) & $\begin{array}{l}1983 \text { IPO Firms } \\
1988 \text { IPO Firms } \\
\text { Significance }\end{array}$ & $\begin{array}{l}-0.8^{+} \\
-1.3^{+}\end{array}$ & $\begin{array}{r}0.2 \\
-0.9\end{array}$ & $\begin{array}{l}0.2 \\
0.5\end{array}$ \\
\hline Op. Inc.-to-Ássets (\%) & $\begin{array}{l}1983 \text { IPO Firms } \\
1988 \text { IPO Firms } \\
\text { Significance }\end{array}$ & $\begin{array}{l}-2.7 \ldots \\
-2.1\end{array}$ & $\begin{array}{r}1.1 \\
-1.0\end{array}$ & $\begin{array}{l}0.6 \\
1.0\end{array}$ \\
\hline Cap. Exp.-to-Assets (\%) & $\begin{array}{l}1983 \text { IPO Firms } \\
1988 \text { IPO Firms } \\
\text { Significance }\end{array}$ & $\begin{array}{l}1.3 \ldots \\
0.6\end{array}$ & $\begin{array}{l}-0.8 \\
-1.5\end{array}$ & $\begin{array}{l}-0.6+ \\
-0.2\end{array}$ \\
\hline \multicolumn{5}{|c|}{$\begin{array}{l}\text { ***.**. }{ }^{*} \text { denote differences between } 1983 \text { and } 1988 \text { medians are significant at } 1 \% .5 \% \text {, and } 10 \% \text {, respectively. } \\
\text { based on a Wilcoxon two-sample ranked sum test. } \\
\text { Wilcoxon signed rank test. }\end{array}$} \\
\hline
\end{tabular}




\section{Table 11}

\section{Long-Run Stock Returns for the 1983 IPOs and 1988 IPOs \\ Over Periods Comparable to Those Based on Compustat Data}

The sample includes firms that completed IPOs in 1983 and 1988. Returns are calculated from CRSP daily share price data. Firms with missing or questionable data on CRSP are excluded from the sample. IPO returns ( $r_{i}$ ) are calculated using daily data (not compounded) from two weeks after the IPO date to the last day of the 1st, 3rd, of 5th full calendar year after the IPO. For each IPO return period, we calculate the return on the Nasdaq $\left(r_{n}\right)$ for the same period, which may be less than a year if the firm delists. The means of each set of observations $\left(r_{i}\right.$ and $\left.r_{n}\right)$ are used to compute wealth relatives $\left(1+r_{i} / 1+r_{n}\right)$.

\begin{tabular}{|c|c|c|c|c|c|c|}
\hline \multirow[b]{2}{*}{ Return period } & \multicolumn{3}{|c|}{1983 IPOS } & \multicolumn{3}{|c|}{1988 IPOS } \\
\hline & $\begin{array}{l}\text { Mean } \\
\text { IPO } \\
\text { Return }\end{array}$ & $\begin{array}{l}\text { Mean } \\
\text { Nasdaq } \\
\text { Return } \\
\end{array}$ & $\begin{array}{l}\text { Wealth } \\
\text { Relative }\end{array}$ & $\begin{array}{l}\text { Mean } \\
\text { IPO } \\
\text { Return } \\
\end{array}$ & $\begin{array}{l}\text { Mean } \\
\text { Nasdaq } \\
\text { Retum } \\
\end{array}$ & $\begin{array}{l}\text { Wealth } \\
\text { Relative }\end{array}$ \\
\hline $\begin{array}{l}\text { Listing to year-end } \\
\text { of next calendar } \\
\text { year }\end{array}$ & -28.7 & -15.3 & .84 & 14.9 & 20.0 & .96 \\
\hline $\begin{array}{l}\text { Listing to year-end } \\
\text { of third full calendar } \\
\text { year }\end{array}$ & -4.9 & 16.8 & .81 & 82.7 & 45.4 & 1.26 \\
\hline $\begin{array}{l}\text { Listing to year-end } \\
\text { of fifth full calendar } \\
\text { year }\end{array}$ & -8.4 & 25.4 & .73 & 166.8 & 78.1 & 1.50 \\
\hline Excluding APCC & - & - & - & 67.9 & 78.1 & .94 \\
\hline
\end{tabular}




\section{Table 12}

\section{Firm Characteristics in Years Following the IPO for Firms that Issued IPOs in 1982 and 1983}

Table values are industry-adjusted medians for IPO firms in 1982 and 1983. Median industry-adjusted sales is the median difference between firm sales and the median sales for firms in its industry as a percent of median sales for firms in its industry. Median industry-adjusted operating income ratios are the median difference between the firm value and the median value for firms in its industry. Operating income is operating income before depreciation, as defined on COMPUSTAT research tapes. Years 1-5 represent calendar years 1982-1987 for the 1982 IPO firms, and calendar years 1983-1998 for the 1983 IPO firms. Year values are based on firms remaining in the sample.

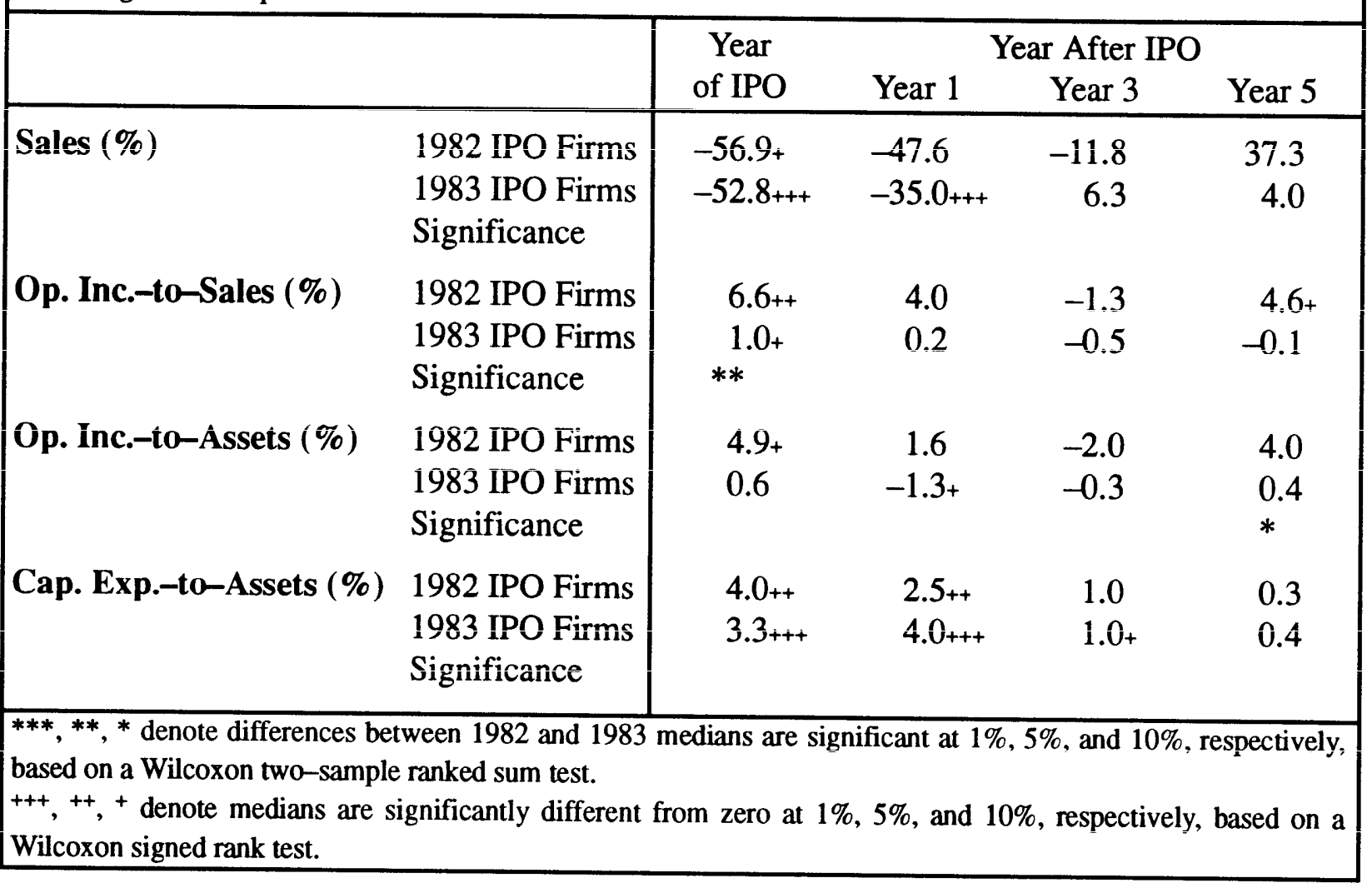


Table 13

\section{Wealth Relatives for Portfolios of Firms that Issued IPOs in 1983 and 1988}

Stock returns are adjusted for dividends and splits for IPO firms in 1983 and 1988. Years 1, 3, and 5 represent calendar years 1984, 1986, and 1988 for the 1983 IPO firms, and 1989, 1991, and 1993 for the 1988 IPO firms. Returns for the IPO firms, $r_{i}$, and NASDAQ, $r_{n}$, are means for the best and worst performing groups over the defined period, defined by firms above the $75^{\text {th }}$ percentile or below the $25^{\text {th }}$ percentile for the combined group of firms. Wealth relatives are calculated as $\left(1+r_{i}\right) /\left(1+r_{n}\right)$.

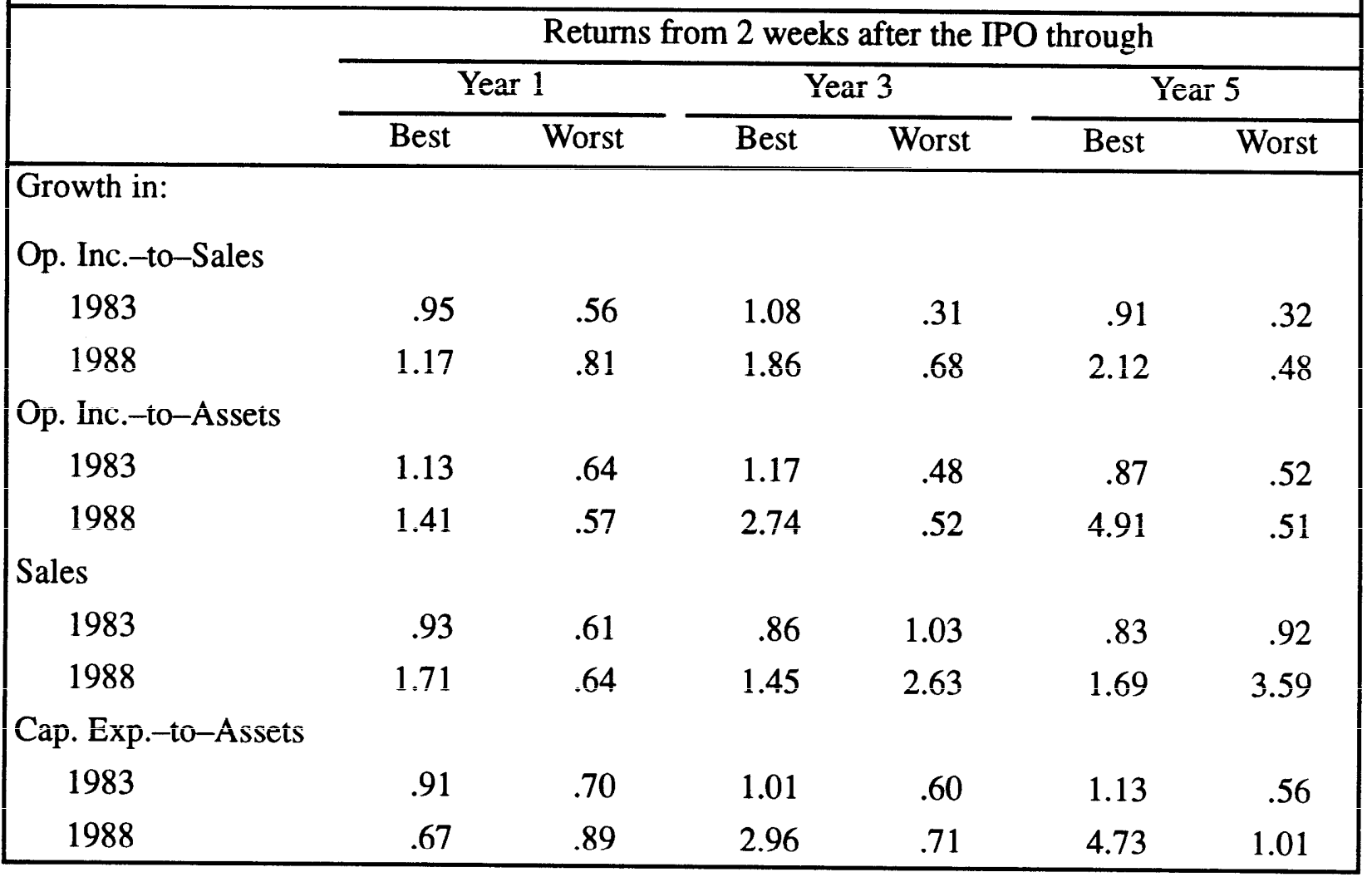

